\title{
Increasing the Wear Resistance of Marine Diesel Engines Elements Made of Ductile Iron
}

\section{Povećanje otpornosti na trošenje elemenata brodskih dizelskih motora koji se izrađuju od nodularnog lijeva}

\author{
Zoran Veljačić \\ Norinco International Cooperation Ltd. \\ Zagreb \\ E-mail: Iveljacic@gmail.com
}

Summary

This paper examines the influence of austempering and shot peening on the wear resistance of ductile iron. Samples for further testing were made from mechanically processed casts. The hardness and microstructure of ductile iron were examined on the prepared samples. Metallographic analysis of ductile cast iron samples in the cast state determined the pearlitic-ferritic structure of the matrix characteristic of this type of cast iron. Pearlite predominates in the structure, and the rest consists of ferrite and graphite nodules. The samples were then austempered. The isothermal conversion was $240^{\circ} \mathrm{C}$. After austempering, the hardness was measured and the microstructure was characterized, and the changes that occurred in relation to the heat-treated ductile iron were studied. Austempering created a new austempered structure, harder than that in the cast state, which led to improved mechanical properties. A needle-like structure of lower bainite (ADI) with high-carbon austenite, untransformed austenite, martensite and graphite nodules was achieved. The selected parameters of the shot peening process deformed the surface of the ADI and achieved a mostly martensitic structure without the presence of a soft phase, which increased resistance to abrasion. Additional hardening of the substrate by the shot peening process resulted in a composite material with the properties of comparative steel parts, which are lighter, cheaper and easier to manufacture, more resistant to wear and quieter in operation. Such material should have an even wider application in mechanical engineering, and thus in the construction of marine machinery and plants.

\begin{abstract}
Sažetak
$U$ radu je ispitan utjecaj izotermičkog poboljšavanja $i$ kugličarenja na otpornost trošenja nodularnog lijeva. Izliveni su odljevci iz kojih su strojnom obradom izrađeni uzorci za daljnja ispitivanja. Na izrađenim uzorcima ispitana je tvrdoća i mikrostruktura nodularnog lijeva. Metalografskom analizom uzoraka nodularnog lijeva u lijevanom stanju utvrđena je perlitno-feritna struktura matrice karakteristična za ovu vrstu lijeva. U strukturi prevladava perlit, a ostatak čine ferit i nodule grafita. Nakon toga uzorci su izotermički poboljšani. Temperatura izotermičke pretvorbe bila je $240{ }^{\circ} \mathrm{C}$. Nakon izotermičkog poboljšavanja izmjerena je tvrdoća i provedena je karakterizacija mikrostrukture te su proučavane promjene koje su nastale u odnosu na toplinski neobrađeni nodularni lijev. Izotermičkim poboljšavanjem nastala je nova ausferitna struktura, tvrđa od one u lijevanom stanju, što je dovelo do poboljšanja mehaničkih svojstava. Ostvarena je ausferitna struktura donjeg bainita igličastog oblika (ADI) s visokougljičnim austenitom, netransformiranim austenitom, martenzitom i nodulama grafita. Odabranim parametrima postupka kugličarenja deformirana je površina ADI i ostvarena uglavnom martenzitna struktura bez prisutne meke faze, što je povećalo otpornost na abrazijsko trošenje. Dodatnim otvrdnućem supstrata postupkom kugličarenja dobiven je kompozitni materijal sa svojstvima komparativnim dijelovima iz čelika, koji su lakši, jeftiniji i jednostavniji za proizvodnju, otporniji na trošenje te tiši u eksploataciji. Takav materijal bi trebao imati još širu primjenu u strojogradnji, a time i u izgradnji brodskih strojeva i postrojenja.
\end{abstract}

DOI 10.17818/NM/2021/3.2

UDK 621.7.01/09: 629.5

Preliminary communication / Prethodno priopćenje Paper accepted / Rukopis primljen: 22. 4. 2021.

KLJUČNE RIJEČI
nodularni lijev
izotermičko poboljšavanje
kugličarenje
trošenje

\section{INTRODUCTION / Uvod}

Due to its good properties, ductile iron is increasingly used in mechanical engineering, and thus in the construction of marine machinery and plants.

Below are some of the examples of the application of ductile iron in the construction of parts of marine engines (engine type is in brackets): piston sleeve, air cylinder - exhaust valve housing part, cylinder pressure connection extensions, crankshaft bearing supports, crankshaft bearing cover and crosshead bearing caps (60MC-C), fuel pump wheel guide and exhaust valve wheel - fuel pump and exhaust valve drive system (50MC-C), oil cylinder - part of the exhaust valve housing (60MC-C (M)), auxiliary marine engine housings, etc.

Since a large part of machine elements is exposed to wear, and in order to find even wider application of ductile iron in their production, this paper is aimed at finding procedures for processing ductile iron in order to increase its wear resistance.

Ductile iron is an iron alloy that has very good mechanical properties, good castability and machinability. In addition, the 
cost of its production is lower compared to steel. Good mechanical properties are achieved already in the cast state. Precisely because of this favourable combination of properties and low production cost, the production of ductile iron is constantly growing and its application is expanding. Ductile iron is still the subject of numerous studies which have established that mechanical properties can be further improved by thermal and mechanical treatments [1, 2].

Thus, previous research has shown that ductile iron can be widely used in mechanical engineering and that it can be a quality and cheaper replacement for some steels. This is especially true for the qualities of ductile iron whose mechanical properties are further improved by subsequent heat treatment - isothermal ductile iron (austempered ductile iron - ADI), which proved to be the most efficient heat treatment of ductile iron, Figure 1. In the edition of the standard HRN EN 1564 from 2011, ADI is defined as austempered ductile iron, because the austempered structure can be achieved today without the application of isothermal conversion [3].
Austempering consists of three phases: austenitizing (A$C)$, quenching (C-D), and isothermal conversion (D-E). The austenitizing temperature ranges from $850-930{ }^{\circ} \mathrm{C}$, and is determined for each alloy by thermal analysis. The quenching rate must be sufficient to avoid the pearlite area before starting the isothermal conversion reaction. The most important phase is the isothermal conversion (between 200 and $400{ }^{\circ} \mathrm{C}$ ) during which the conversion of metastable austenite to ausferrite (D-E) occurs. The isothermal conversion temperature and the holding time at that temperature are crucial for the mechanical properties of the ADI material. Lower temperature causes greater cooling of austenite and the formation of more ferrite dust and causes the formation of a finer ausferrite structure resulting in high strength, relatively high hardness and low ductility, while higher temperature (above $350^{\circ} \mathrm{C}$ ) causes the formation of coarser ausferrite structure with lower strength, lower hardness and high ductility [5,6], Figure 2.

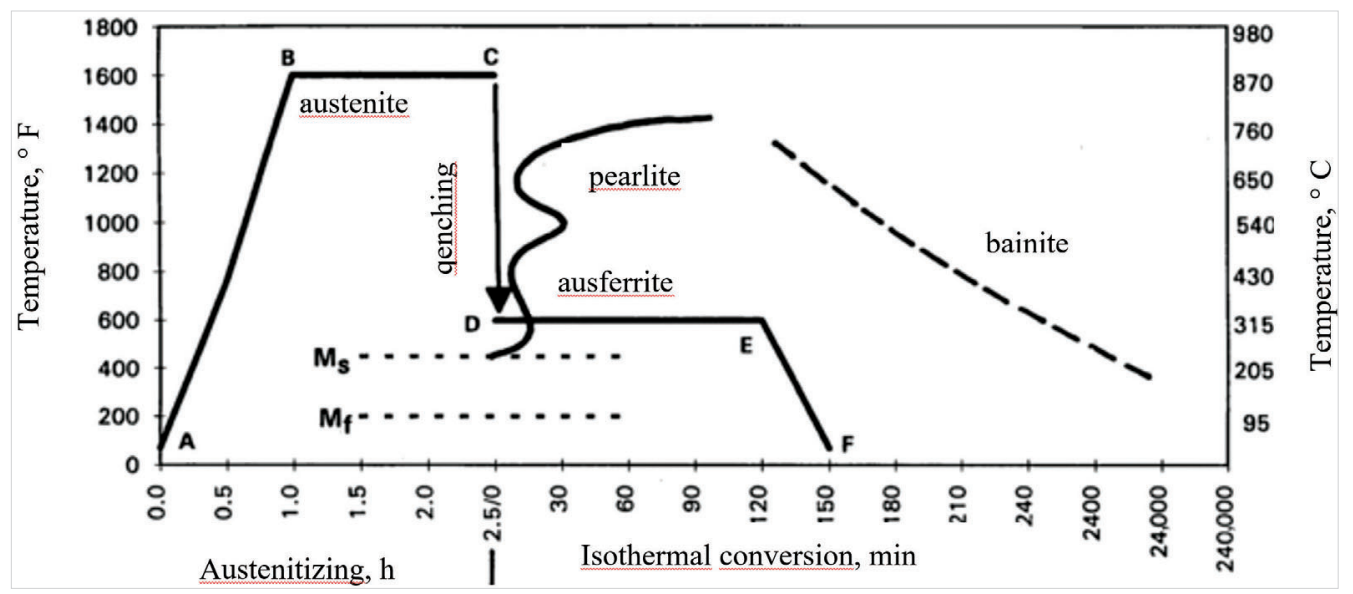

Figure 1 Schematic representation of the austempering process [4]

3 phases: austenitizing $(A-C)$, quenching $(C-D)$ and isothermal conversion (D - E)

Slika 1. Shematski prikaz procesa izotermičkog poboljšavanja [4]

3 faze: austenitiziranje $(A-C)$, kaljenje (C - D) i izotermička konverzija (D - E)

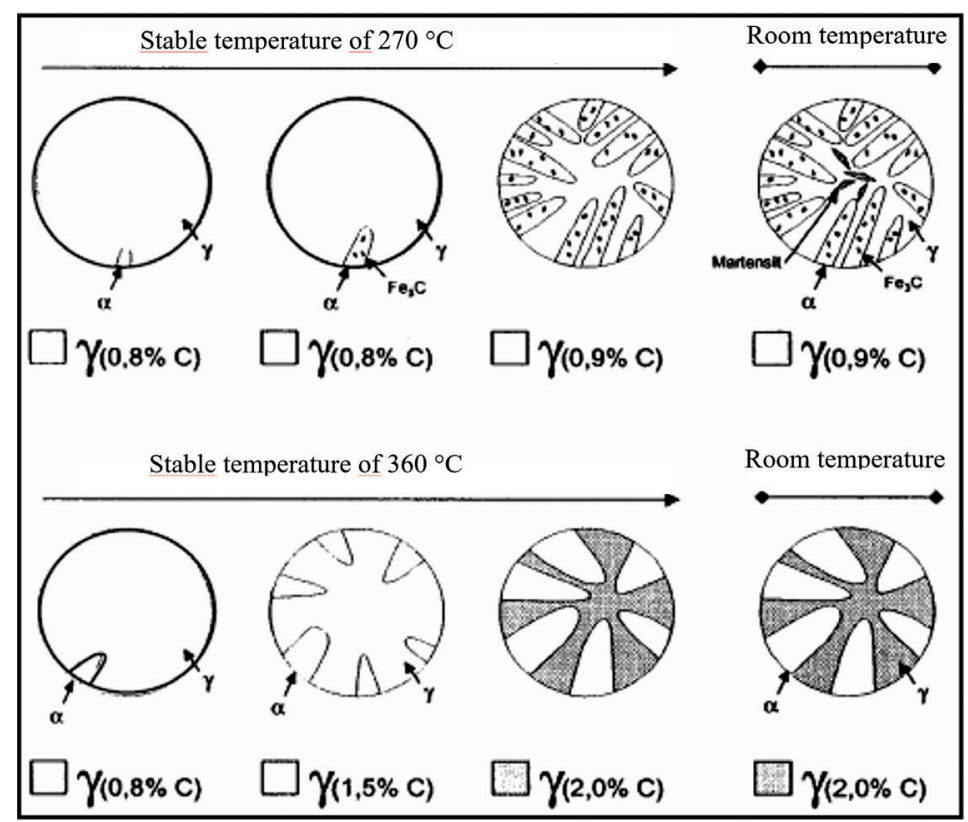

Figure 2 Schematic representation of austenite to ADI conversion at different temperatures [5]. Slika 2. Shematski prikaz konverzije ausferita u ADI na različitim temperaturama [5] 
Today, different types of austempered ductile iron with properties depending on the time and temperature of austenitization and isothermal conversion and the chemical composition of the cast material are used. By combining these parameters, very good properties of ADI material can be achieved, with tensile strength up to $1700 \mathrm{MPa}$, hardness up to $480 \mathrm{HB}$ and elongation $1-16 \%[7,8]$.

Figure 3 shows that ADI has twice the strength of ductile iron for the same level of ductility and its strength is comparable to alloy steels. Today, ADI is used for many components in mechanical engineering such as gears and crankshafts.

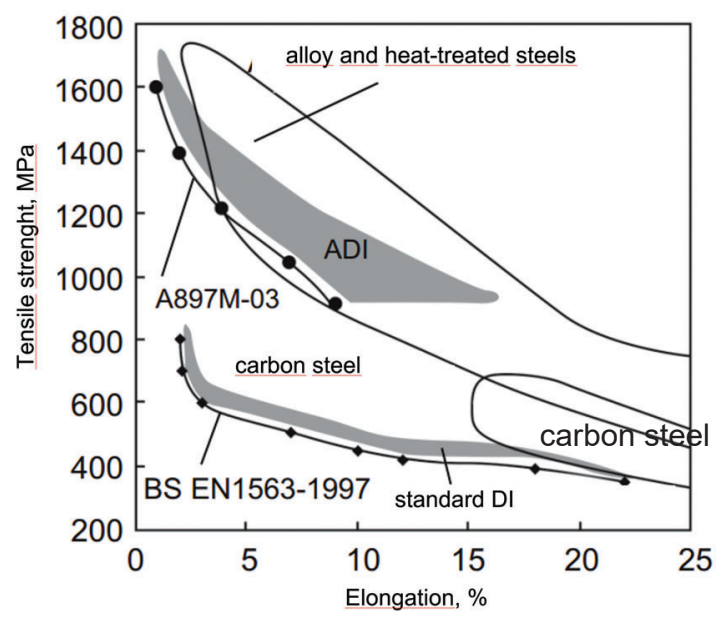

Figure 3 Comparison of the properties of ADI materials with steels and standard ductile iron [7].

Slika 3. Usporedba svojstava ADI materijala s čelikom i standardnim nodularnim lijevom [7]

Even better properties and wear resistance of ADI can be achieved by additional mechanical surface treatment procedures: hammering or shot peening.

In this paper, the selected mechanical surface treatment procedure was the shot peening procedure. It is a process in which shots in a jet hit the surface at high speed.

The shot peening process is a controlled technological process which, under normal environmental conditions, achieves plastic deformation, i.e., it introduces compressive stress into the surface layer of metal [9].

By the introduction of plastic deformations at room temperature, a surface microstructural change occurs, the residual austenite turns into martensite $[10,11]$.

The effect of shot peening depends on the intensity (strength) of shot peening. The intensity of shot peening depends on the size, shape, hardness, material, speed and impact of the shots. To check the intensity of shot peening, the Almen method is used, based on the measurement of the test strip (Almen bow) formed after shot peening.

The effects of cold deformation caused by shot peening are observed at a depth of up to $1 \mathrm{~mm}$ [12].

\section{EXPERIMENTAL SECTION / Eksperimentalni dio}

Ductile iron EN-GJS-600-3 with a predominant pearlitic structure was selected for this study, due to good mechanical properties (already in the cast state) and the possibility of their further improvement by austempering and shot peening.

\subsection{Casting and Making Samples / Lijevanje i pravljenje uzoraka}

The production of ductile iron melt and casting of test samples was carried out in a certified foundry Brodosplit d.d., during the casting of six pieces of oil cylinders of the marine engine $6 \mathrm{~S} 50 \mathrm{MC}-\mathrm{C}$, Figure 4.

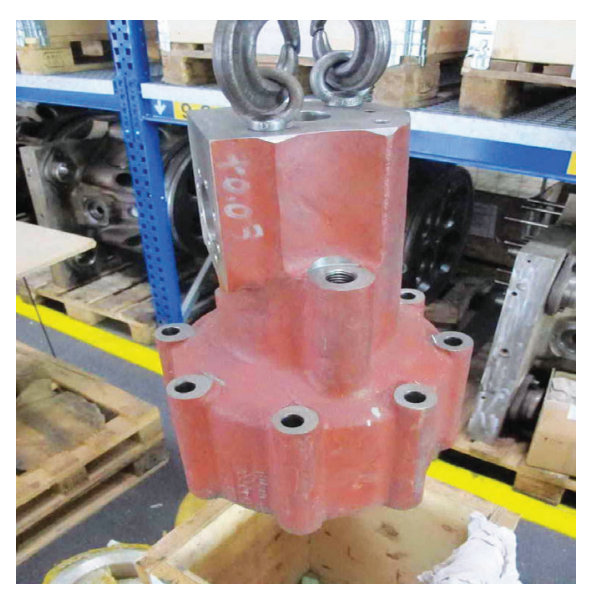

Figure 4 Oil cylinders MAN B\&W 6S50 MC-C Slika 4. Cilindri za ulje MAN B\&W 6S50 MC-C

The primary melt for making ductile cast iron was prepared in a mains-frequency induction furnace. The cartridge consisted of low manganese pig iron, steel scrap, circular material and ferroalloys FeSi75 and FeMn75. Chemical analysis was performed before pouring into the ductile pot. After obtaining the melt of the required chemical composition, it was poured into a ductile pot at a temperature of $1520^{\circ} \mathrm{C}$, where vaccination was performed. Nodulation was performed by Tundish cover procedure. The melt was further grafted into the jet when poured into the mould.

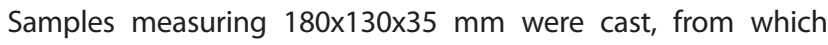
abrasion test specimens were later machine-made.

The dimensions of the samples are $13 \times 22 \times 73 \mathrm{~mm}$.

Hardness was measured on the same samples and metallographic tests were performed.

\subsection{Austempering / Izotermičko poboljšavanje}

Austempering was performed in the Heat Treatment Laboratory, Department of Materials and Tribology, Department of Production Engineering, Faculty of Electrical Engineering, Mechanical Engineering and Naval Architecture in Split. Abrasion test samples were improved to a temperature of $240^{\circ} \mathrm{C}$, Figure 5 .

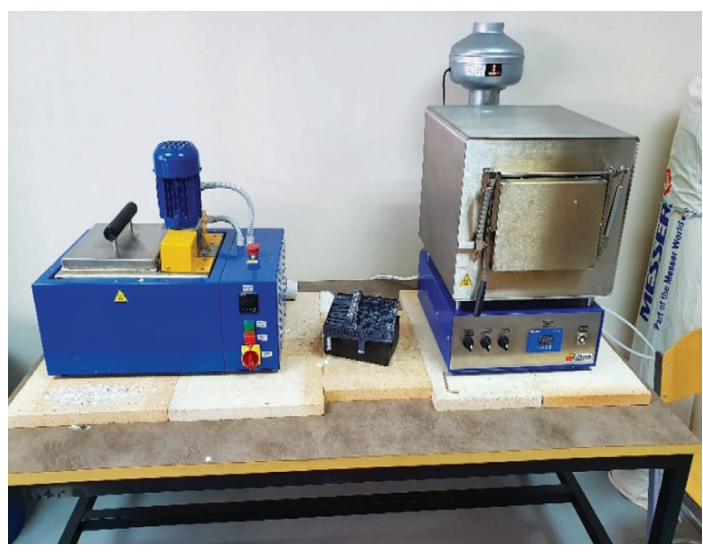

Figure 5 Bath, samples after ADI procedure, furnace Slika 5. Kada, uzorci nakon ADI postupka, peć 
The process consisted of heating to an austenitization temperature of $900^{\circ} \mathrm{C}$, holding for one hour at that temperature, and rapid cooling to an isothermal conversion temperature. The samples were rapidly cooled and kept for one hour in an AS 140 salt bath at $240{ }^{\circ} \mathrm{C}$, followed by gradual cooling in air to room temperature, Figure 6.

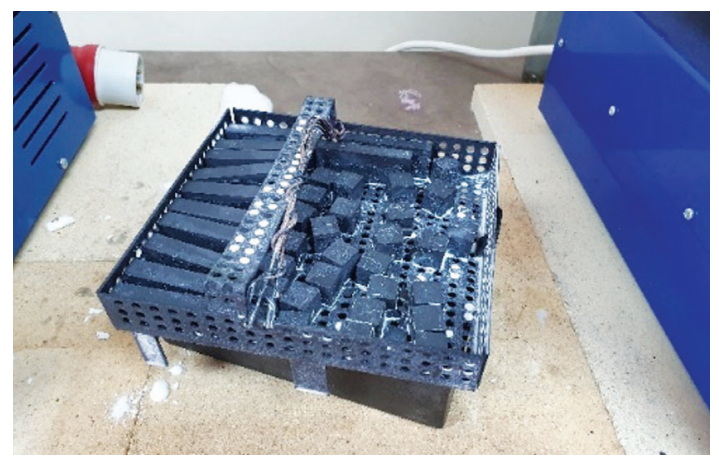

Figure 6 Samples after air cooling Slika 6. Uzorci nakon hlađenja zrakom

After cooling, the samples were washed with water to remove salt residues.

The heating and cooling process is diagrammatically shown in Figure 7. The isothermal conversion was selected according to the literature $[13,14]$.

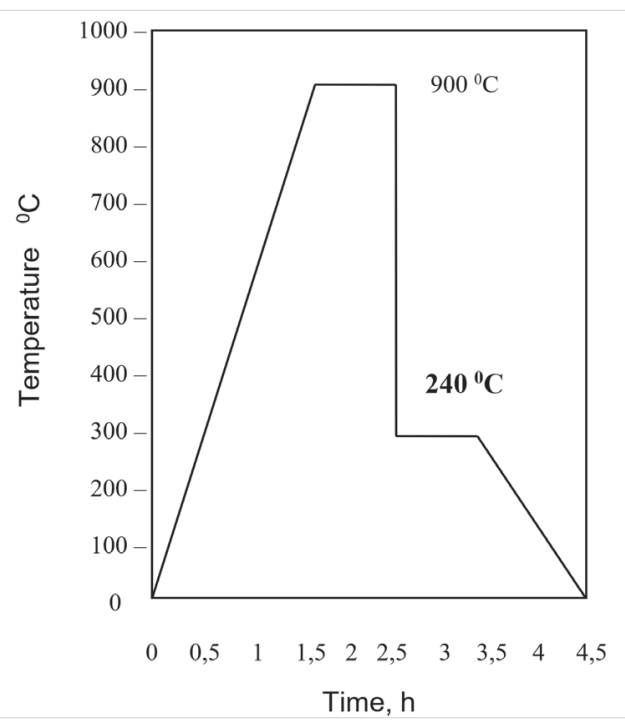

Figure 7 Austempering diagram Slika 7. Dijagram izotermičkog poboljšavanja

\subsection{Shot Peening / Kugličarenje}

Shot peening was done using a shot peening device UZK-1, Figure 8.

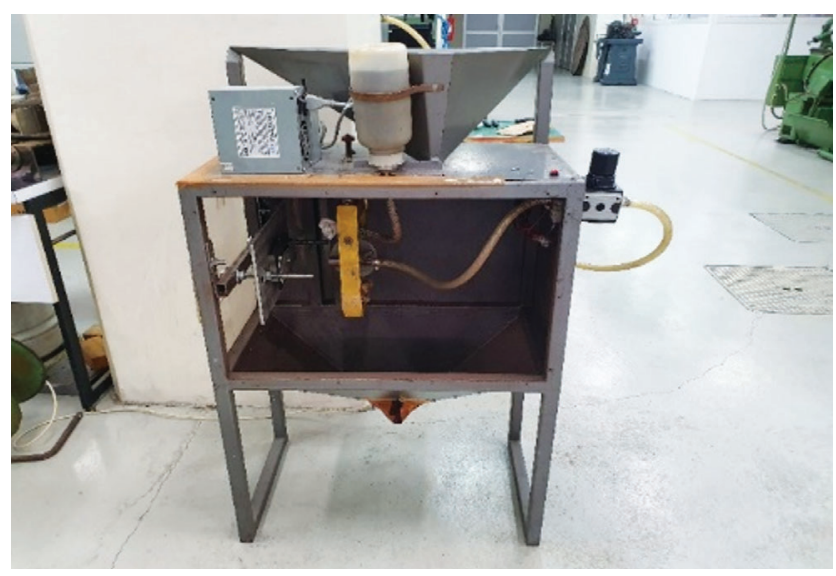

Figure 8 Shot peening device UZK-1 Slika 8. Uređaj za kugličarenje UZK-1

The shot peening agent used is a high-carbon heat-treated granulate Abrasiv Muta S 390 (Ø $1 \mathrm{~mm}$ ). Prior to the shot peening of the wear test specimens, calibration of the shot peening device had to be performed.

The following parameters are defined:

$\begin{array}{lr}\text { Pressure } & \text { Almen intensity } \\ 7 \text { bar } & \text { "1,19 A" } \\ 5,6 \text { bar } & \text { "1,04 A" } \\ 4,7 \text { bar } & \text { "0,94 A" }\end{array}$

\subsection{Abrasion Resistance Test / Test otpornosti na abraziju}

The standard method of "dry sand/rubber wheel" was used for experimental determination of abrasion resistance (Figure 9). Quartz sand $\mathrm{SiO}_{2}$ with a granulation of $0.25-0.50 \mathrm{~mm}$ was used as the abrasive medium.

The sample rests on a rubber-coated wheel (2) (hardness about 60 Shore A) and is loaded with weights over the crankshaft. The force $\mathrm{F}$ is $45 \mathrm{~N}$ or $130 \mathrm{~N}$, depending on the process variant. The total number of wheel revolutions is variable and is registered by a counter. In the case of this test used force was $130 \mathrm{~N}$. Sample mass loss was measured by weighing after 100 , 200 and 300 revolutions.

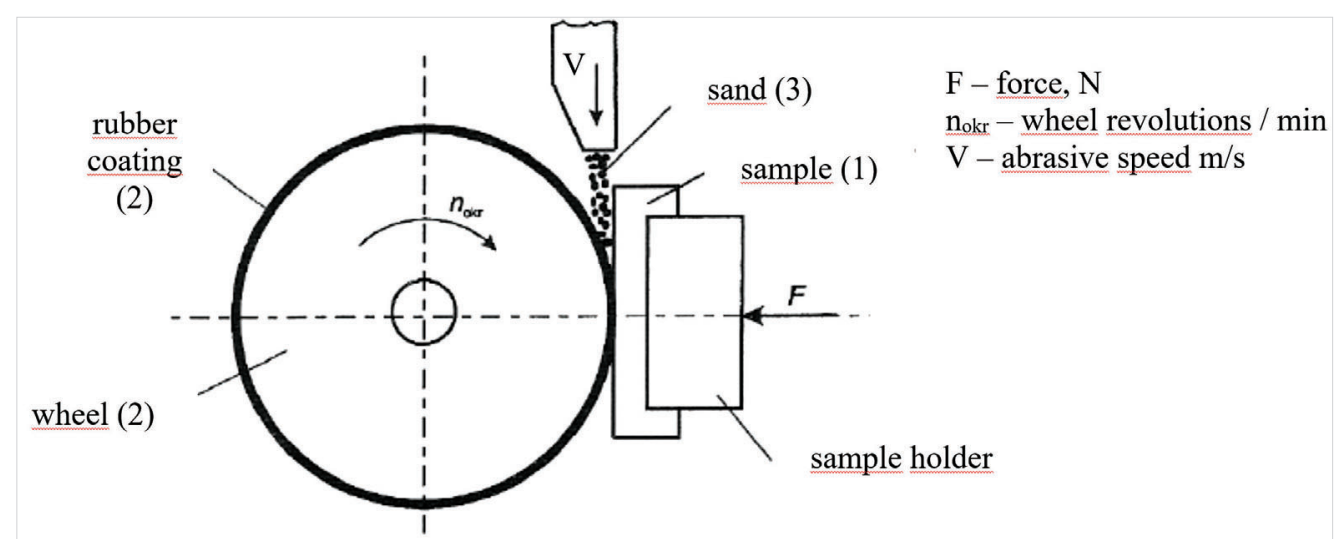

Figure 9 Sketch of the device "dry sand/rubber wheel" [15] Slika 9. Skica uređaja „suhi pijesak/gumeni kotač" [15] 


\section{RESULTS / Rezultati}

\subsection{Ductile Iron / Nodularni lijev}

\subsubsection{Chemical Composition / Kemijski sastav}

Table 1 shows the chemical composition of ductile iron EN-GJS-600-3.

Table 1 Chemical composition of ductile iron Tablica 1. Kemijski sastav nodularnog lijeva

\begin{tabular}{|c|c|c|c|c|c|c|c|}
\hline $\mathrm{C} \%$ & $\mathrm{Si} \%$ & $\mathrm{Mn} \%$ & $\mathrm{P} \%$ & $\mathrm{~S} \%$ & $\mathrm{Cu} \%$ & $\mathrm{Mg} \%$ & $\mathrm{Fe} \%$ \\
\hline 3,57 & 2,49 & 0,113 & 0,029 & 0,007 & 0,4 & 0,057 & rest \\
\hline
\end{tabular}

\subsubsection{Hardness / Tvrdoća}

The surface hardness was tested with the Rockwell method on three samples, using the device shown in Figure 10. The measured mean value was $18 \mathrm{HRC}$.

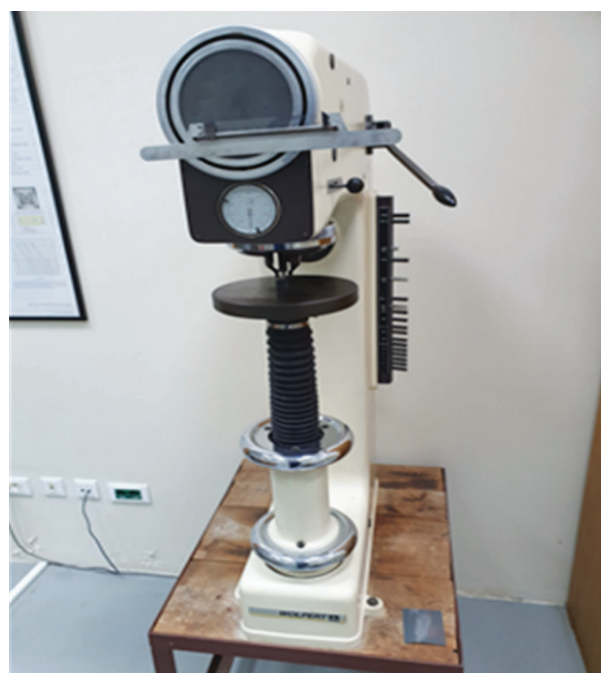

Figure 10 Wolpert hardness tester Slika 10. Wolpert tester čvrstoće

\subsubsection{Microstructure (Cast State) / Mikro struktura (izljev)}

Based on the performed metallographic analysis, Figure 11, it was concluded that the graphite was mostly excreted in the form of nodules. The shape and size of the nodules were determined according to the standard HRN EN ISO 945-1: 2011. Graphite nodules are of form $\mathrm{VI}$, size $5 / 6$, in a large percentage regular $(80-85 \%)$ and evenly distributed in the structures. Upon cooling and solidification of ductile cast iron with increased pearlite content, in the early stage of eutectoid conversion, a significant amount of pearlite is formed at the boundaries of austenitic grains, after which the formation of pearlite dominates by eutectoid conversion. The growth rate of pearlite is significantly higher than the growth rate of ferrite, so after the beginning of pearlite formation, little ferrite is formed [16].

The matrix is pearlite-ferrite, and the ferrite is distributed around graphite nodules, which is a consequence of the diffusion of carbon to graphite nodules. Copper is an element that influences the development of pearlite, settles around the nodule and prevents the diffusion of carbon from austenite to the nodule, and in eutectoid conversion austenite is largely transformed into pearlite.

Volume fraction of phases in the base material: pearlite - $61,4 \%$; ferrite $-26,4 \%$; graphite - $12,2 \%$; no. nodules/ $\mathrm{mm}^{2}-129$

Figure 11 shows the microstructure of the EN-GJS-600-3 recorded using a light microscope.

\subsection{Austempered ductile iron (ADI) / Nodularni lijev izotermički poboljšan (ADI)}

\subsubsection{Hardness / Tvrdoća}

The surface hardness of ADI 240 was tested on the same device on which the samples of cast iron were tested, Figure 10. The average measured value is $35.2 \mathrm{HRC}$.

\subsubsection{Microstructure after isothermal conversion at $240^{\circ} \mathrm{C} /$} Mikro struktura nakon izotermalne konverzije na $240^{\circ} \mathrm{C}$ At an isothermal conversion temperature of $240{ }^{\circ} \mathrm{C}$, the subcooling of austenite was higher, the diffusion of carbon was slower, and a structure of finer ausferrite was formed, Figure 12. Ferrite germination is favoured over ferrite growth due to high hypothermia. In this way only a small proportion of carbon can diffuse from ferrite to austenite. Part of the carbon is excreted in the form of carbides within the ferrite grains. The remaining austenite is only slightly enriched in carbon, $0.9 \%$ and remains unstable, Figure $2[5,6]$. The proportion of metastable austenite can subsequently be converted to martensite when cooled to room temperature, which was obtained in this study at a temperature of $240^{\circ} \mathrm{C}$, Figure 12. Isolated white areas show plate austenite, while carbon-rich austenite is found around the ferrite needles of bainite ferrite. The needle shape is characteristic of the lower bainite ferrite.

Figure 12 shows the ausferrite structure formed at lower isothermal conversion temperatures.

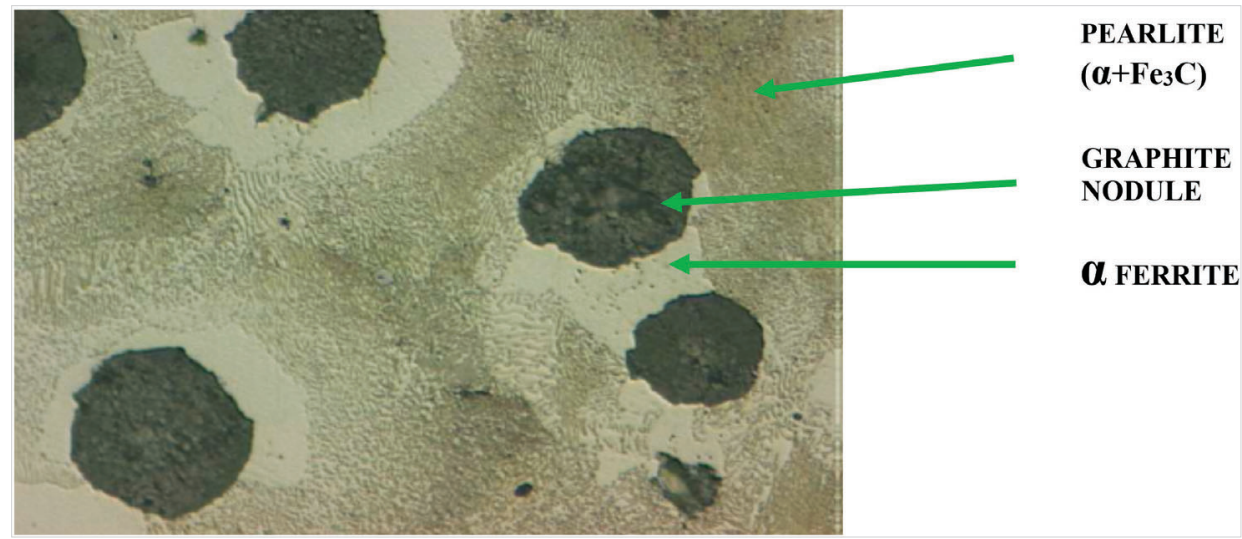

Figure 11 Microstructure EN-GJS-600-3 recorded Slika 11. Mikro struktura EN-GJS-600-3 zabilježena 


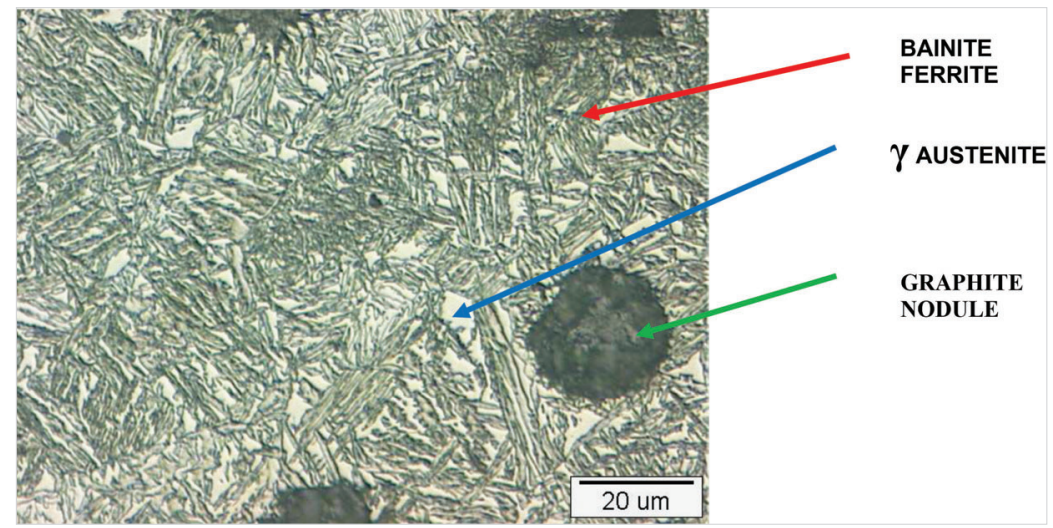

Figure $12 \mathrm{ADI} 240$ at 500X magnification

Slika 12. ADI 240 uvećano 500X

\subsection{ADI Shot Peening (ADI $240 \mathrm{~K}$ ) / ADI kugličarenje (ADI $240 \mathrm{~K})$}

In order to achieve the set shot peening intensities, it was necessary to provide the required air pressure.

During shot peening, the pressure at the inlet to the shot peening device drops by a certain amount, which depends on the capacity of the compressor and its associated tank.

In order to achieve a continuous operating pressure of $7 \mathrm{bar}$ (Figure 13), the pressure at the inlet to the device should have been $\min .7 .6$ bar.

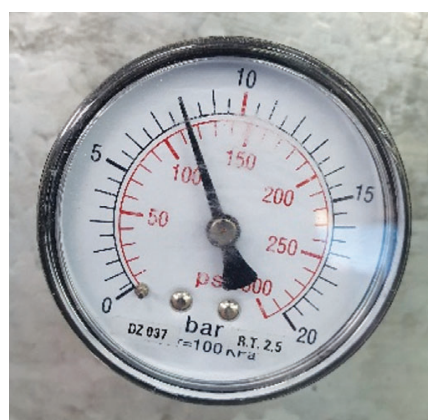

Figure 13 Manometer at the outlet of the air tank (condition during the shot peening process)

Slika 13. Manometar na izlazu spremnika za zrak (stanje za vrijeme procesa kugličarenja)

At an inlet pressure of 6 bar, a drop of 0.4 bar was achieved in shot peening, which means that the continuous working pressure was 5.6 bar. For an inlet pressure of 5 bar, the pressure drop was 0.3 bar, i.e., an operating pressure of 4.7 bar was achieved.
With the aforementioned pressures, the planned shot peening intensities were achieved: "1.19 A" (7 bar), "1.04 A" (5.6 bar)" and "1.19 A" (7 bar).

\subsection{Hardness ADI $240 \mathrm{~K} /$ Tvrdoća ADI $240 \mathrm{~K}$}

The surface hardness was tested on three samples, two samples with a shot peening intensity of " $1.19 \mathrm{~A}$ " and one sample with a shot peening intensity of " $0.94 \mathrm{~A}$ ".

In the first case, the average hardness is $39 \mathrm{HRC}$, and in the second $37.8 \mathrm{HRC}$.

The same measuring device was used as in the previous two cases.

\subsection{Testing of abrasion resistance / Testiranje otpora na abraziju}

Table 2 shows the mass loss of non-shot-shaped and differentintensity shot-shaped ADI samples, measured after 100, 200 and 300 revolutions.

Table 2 Mass loss due to abrasion with $\mathrm{SiO}_{2}$ abrasive Tablica 2. Gubitak mase uslijed abrazije $\mathrm{SiO}_{2}$ abrazivom

\begin{tabular}{|c|c|c|c|c|}
\hline $\begin{array}{c}\text { Number of } \\
\text { revolution }\end{array}$ & ADI & „0,94 A“ & „1,04 A“ & „1,19 A" \\
\hline 100 & 61.8333 & 33.6667 & 21.4000 & 27.8000 \\
\hline 200 & 90.2333 & 62.4667 & 32.3333 & 57.0000 \\
\hline 300 & 116.9333 & 95.8000 & 43.6333 & 84.3667 \\
\hline
\end{tabular}

Figure 14 gives a diagrammatic representation of the results from Table 2.

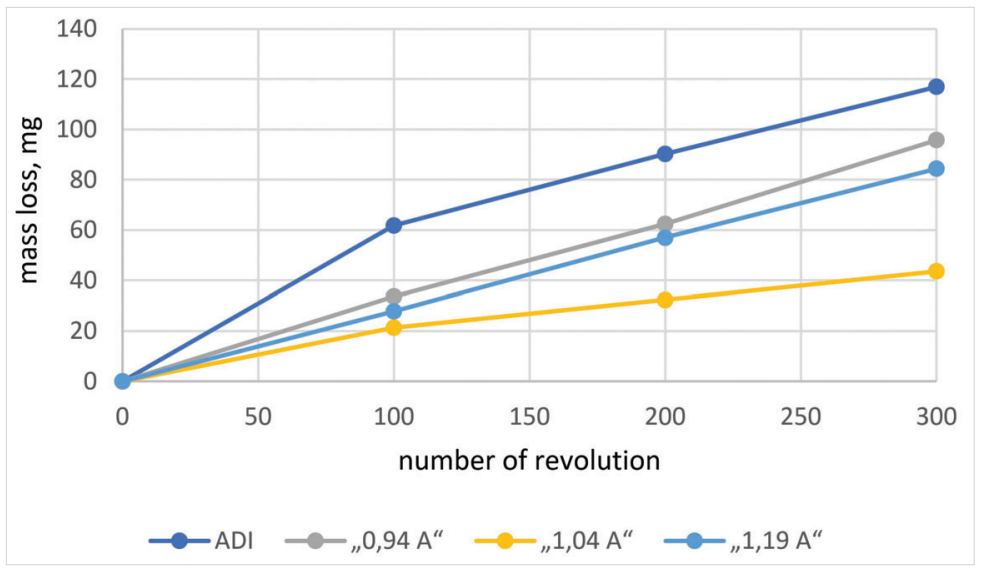

Figure 14 Diagram representation of mass loss due to abrasion Slika 14. Dijagram s prikazom gubitka mase uslijed abrazije 


\section{CONCLUSION / Zaključak}

Based on the tests performed in this paper, the following is concluded:

- Microstructure analysis shows an orderly structure in heattreated samples. The structure of these samples consists of graphite nodule with a pearlite-ferrite matrix.

- Austempering of ductile cast iron resulted in a new ausferrite structure that is also homogeneous.

- Austempering at a temperature of $240{ }^{\circ} \mathrm{C}$ resulted in an ausferrite structure of needle-shaped lower bainite with metastable austenite, martensite and graphite nodules.

- Isothermal conversion at a temperature of $240^{\circ} \mathrm{C}$ resulted in a significant increase in surface hardness.

- With shot peening, the hardness increased even more. Higher surface hardness was achieved with higher intensity shot samples.

- By abrasion of non-shot samples, a higher weight loss was achieved compared to shot samples.

- The highest total mass loss, after three test cycles (3×100 rpm), was achieved with the lowest intensity shot samples. On the other hand, the highest intensity of shot peening did not achieve the highest resistance to abrasion wear, because the best results were given by shot peening with a medium intensity of " $1.04 \mathrm{~A}^{\prime}$. The smallest deviation of mass loss per cycle was achieved in the samples "1.04 A".

\section{REFERENCES / Literatura}

[1] I. C. H. Hughes: Ductile Iron, Metals Handbook, Ninth Edition, Volume 15, Casting, ASM International, Metals Park Ohio, SAD, 2008.

[2] M. Gagné, The Sorelmetal Book of Ductile Iron, Rio Tinto Iron \& Titanium, Montreal, Kanada, 2004

[3] ..., HRN EN 1564 : 2012 - Ljevarstvo - Izotermički poboljšani nodularni lijev, Founding - Ausferritic spheroidal graphite cast irons.

[4] ..., available on: www.aditreatments.com [01.02.2014.]

[5] M. Hadi: Einfluss von Nickel auf Herstellung und Eigenschaften von bainitischem Gusseisen mit Kugelgraphit, Doktorski rad, Technische Universität Bergakademie Freiberg, 2007.

[6] M.A. Yescas-Gonzalez, Modelling the microstructure and mechanical properties of austempered ductile irons, Doktorski rad, University of Cambridge, 2001.

[7] J. Liu: Unique microstructure and excellent mechanical properties of ADI, China foundry 3 (4), 2006.

[8] ..., available on: www.russellductile.co.uk [31.01.2014.].

[9] J. C. Straub, Shot Peening-Theory, 1962. http://www.shotpeener.com/library/ pdf/1962005.pdf

[10] A. Polishetty, Machinability and microstructural studies on phase transformations in Austempered Ductile Iron, Auckland University of Technology, 2011.

[11] A.Cristina, A.Manuel, Mecanismos de deformacion en aceros inoxidables metaestables, Universitat Politecnica de Catalunya, 2011., www.recercat. net/.../2011FI_B2\%2000256.pdf?.....

[12] R. Markovina, Istraživanje utjecaja plastičnog deformiranja površinskih slojeva elemenata na njihova nosiva svojstva, Doktorska disertacija, Strojarski fakultet, Mostar, 1991.

[13] F. Cajner, D. Landek: Svojstva i primjena izotermički poboljšanog nodularnog lijeva, Ljevarstvo 46, 2004.

[14] B. Liščić, I. Katavić, Izotermički poboljšani žilavi lijev i njegova primjena za visokoopterećene elemente, Ljevarstvo 32, 1985.

[15] V. Ivušić, Tribologija, Fakultet strojarstva i brodogradnje, Zagreb, 2002.

[16] Z. Glavaš, F. Unkić: Lijevanje željeznih metala, Metalurški fakultet, Sisak 2008. 